\title{
1 Bioavailability of nutrients and harmful elements in ash fertilizers: effect of granulation
}

2

3 Janne Pesonen $^{\mathrm{a}^{*}}$, Toivo Kuokkanen ${ }^{\mathrm{a}}$, Pasi Rautio ${ }^{\mathrm{b}}$, Ulla Lassi ${ }^{\mathrm{a}}$

4

$5 \quad{ }^{a}$ Research Unit of Sustainable Chemistry, P.O. Box 3000, 90014 University of Oulu, Finland

6 bNatural Recourses Institute Finland, Eteläranta 55, 96300 Rovaniemi, Finland

7

$8 \quad$ Corresponding author

9 janne.pesonen@oulu.fi

$10 \quad$ Tel +358294 481647

$11 \quad$ Fax +3588344064

12

13 Abstract

14

15 Environmental policies of the European Union (EU) aim to increase the amount of renewable energy

16 and to improve the use of waste streams. This will increase the amount of fly ash (FA) from biomass

17 combustion, thereby increasing the need for its utilization. Biomass FA is a good fertilizer since it

18 contains most of the nutrients that plants need. Sequential leaching would provide a more accurate

19 assessment of the potential bioavailability of the harmful elements and nutrients than the pseudo-total

20 and/or water-soluble concentration analysis that EU environmental legislation typically requires. This

21 study investigated the effect of granulation and ammonium sulfate addition on the solubility and

22 bioavailability of nutrients and harmful elements from peat and wood co-combustion FA by using

23 sequential leaching and pseudo-total acid digestion. The recoveries of the easily bioavailable nutrients

$24 \mathrm{Ca}, \mathrm{K}, \mathrm{Mg}, \mathrm{P}$, and $\mathrm{S}$ as well as the total bioavailability of $\mathrm{Ca}, \mathrm{K}, \mathrm{Mg}$, and $\mathrm{S}$ reduced significantly after 
25 granulation. Therefore, granulation reduced the fertilizing effect of FA. The pseudo-total recovery of

$26 \mathrm{Ca}, \mathrm{Mg}$, and $\mathrm{S}$ reduced after granulation, indicating that these types of FA form some very stable

27 silicate compounds besides the common self-hardening products. Ammonium sulfate addition

28 increased the recoveries of the easily bioavailable nutrients and total bioavailability recoveries of the

$29 \mathrm{Ca}, \mathrm{K}$, and $\mathrm{Mg}$ back to the same levels as those in FA. The total bioavailability of the harmful elements

$30 \mathrm{As}, \mathrm{Cd}, \mathrm{Cr}, \mathrm{Cu}, \mathrm{Ni}, \mathrm{Pb}$, and $\mathrm{Zn}$ was very low, and this does not limit the usability of $\mathrm{FA}$ as a fertilizer.

32 Keywords: Fly ash; Granulation; Fertilizers; Leaching; Waste utilization

34 1. Introduction

36 One of the main priorities of the EU growth strategy (Europa 2020) is sustainability, which forms the

37 basis of a low-carbon economy [1]. A low-carbon economy is achieved through reductions in

38 greenhouse gas emissions and increases in both renewable energy sources and energy efficiency. The

39 aims of the EU circular economy strategy are to increase recycling and re-use of products and waste

40 materials [2]. The EU Waste Framework Directive (2008/98/EC) [3] includes a 5-step waste hierarchy,

41 which describes the different options available for dealing with the waste. The first goal of the waste

42 hierarchy is the prevention of waste streams. If this is not possible, the next step down the hierarchy is

43 the preparation of waste for re-use, followed by recycling and other recovery (e.g., energy recovery),

44 and finally, if none of the initial 4 steps are feasible, waste should be disposed of by ecologically

45 beneficial methods.

46 The forest and power industries produce large amounts of fly ash (FA) every year in Europe. A

47 large part of this ash ends up at waste disposal sites, even though it could be productively utilized.

48 Changes to the legislation, the Europa 2020 growth strategy, and the EU circular economy strategy 
49 have increased the need to utilize different combustion ashes. The most natural way to utilize biomass-

50 based FA is to use it as a fertilizer or soil amendment. In particular, wood FA contains all the

51 macronutrients plants need in almost the correct proportions, excluding nitrogen $(\mathrm{N})$, which is released

52 into the atmosphere during combustion [4]. In peatlands, nitrogen levels are usually naturally high,

53 whereas phosphorous $(\mathrm{P})$ and potassium $(\mathrm{K})$ are the growth-limiting nutrients. Therefore, FA has great

54 potential as fertilizers for use in peatland forests. It has in fact been shown that FA can outperform

55 commercial PK fertilizers for improving tree growth [5] as well as the financial performance of forest

56 management on peatlands [6].

57 In Finland, to prevent dust problems, FA has to be granulated before application on fields or

58 forests. Granulation is known to be a significantly more cost-effective alternative for ash recycling

59 compared with unprocessed FA mainly due to improved logistics [7]. Co-granulation of FA with some

60 nitrogen containing material such as hygienized sewage sludge could produce new fertilizer products to

61 nitrogen poor soils [8].

62 The EU environmental legislation typically requires that the pseudo-total concentrations (i.e.

63 acid-leachable metals that are not part of silicate matrix) and/or water-soluble concentrations of the

64 harmful elements be studied from waste and residue materials [9-12]. This does not give an accurate

65 representation of the environmental risks associated with the utilization or disposal of these materials.

66 From an environmental point of view, of utmost importance is not the total concentration in wastes and

67 other residues, but rather the ease with which the metals can be mobilized into the environment and

68 their bioavailability. The water-soluble concentration is not a sufficient measure of the environmental

69 risks because distilled or deionized water used in these tests does not represent the normal salt

70 concentration or the ionic strength of the soil solution. Further, rainwater is usually clearly acidic

71 nowadays. The water-soluble concentration measures only the instantly bioavailable fraction of the

72 contaminants and does not evaluate the potential of contaminants to become more available with time 
$73[13,14]$. Moreover, these procedures are not sufficient to assess the bioavailability of nutrients from

74 FA-based fertilizers. Therefore, to obtain more detailed information about the effect of environmental

75 conditions on the bioavailability and mobility of different contaminants, sequential leaching has been

76 widely used with different environmental samples over the past decades [15].

77 In the sequential leaching procedure, various types of increasingly severe chemical reagents are

78 applied to the sample; this procedure divides the total extractable metal concentration into fractions in

79 order to assess the bioavailability and the form in which the metals occur in a waste material.

80 Therefore, compared to the pseudo-total concentrations, the sum of the fractions can give a more

81 accurate assessment of the potential total bioavailability of the harmful elements. Sequential leaching

82 does not necessarily mean total decomposition, and the cumulative extractable recoveries are usually

83 clearly lower than the total concentrations.

84 In this study, the effect of granulation and ammonium sulfate addition on the solubility and

85 bioavailability of nutrients and heavy metals from peat and wood co-combustion FA was studied using

86 the sequential leaching procedure and pseudo-total acid digestion. Although granulation is a standard

87 procedure to improve the handling of FA-based fertilizers, such a study has not been implemented

88 before.

89

90 2. Materials and methods

91

$92 \quad 2.1$ Raw materials and granulation

93

94 The FA used in this study was from a 96-MW thermal power plant situated in Rovaniemi, Northern

95 Finland. The power plant uses a circulating fluidized bed combustion technique. The fuels used at the

96 plant are wood and peat. The fuel ratios (dry mass) at the power plant were approximately 50\% wood 
97 (logging residue) and 50\% peat. The sample was collected 14.5.2014 directly from ash silo.

98 Commercial $350 \mathrm{~g} \cdot \mathrm{L}^{-1}$ ammonium sulfate solution (Envor, Finland) was used in the granulation 99 process of granule FAGR2 (see below).

100 The compositions and sample names of the FA granules used in this study are presented in Table

101 1. For each granule type, a few kilograms were produced. Granule FAGR1 contained only FA and

102 water, whereas granule FAGR2 also contained ammonium sulfate solution. While agitating the FA

103 using a ribbon blade agitator, water (and ammonium sulfate solution) was slowly added to the FA until

104 small aggregates started to form in the paste. The pastes were granulated using a simple pan granulator.

105 A very strong odor of ammonia was observed during FAGR2 granulation. The granules were cured in a

106 hot air oven at $50 \pm 2{ }^{\circ} \mathrm{C}$ for $24 \mathrm{~h}$ and stored at room temperature $\left(21^{\circ} \mathrm{C}\right)$.

107

108 Table 1. Composition and sample names of the FA granules.

\begin{tabular}{llll}
\hline Sample & FA mass fraction $(\%)$ & $\begin{array}{l}\text { Water mass } \\
\text { fraction }(\%)\end{array}$ & $\begin{array}{l}\text { Ammonium sulfate mass } \\
\text { fraction }(\%)\end{array}$ \\
\hline FAGR1 & 60 & 40 & - \\
FAGR2 & 66 & 28 & 6 \\
\hline
\end{tabular}

109

110

\subsection{Sequential leaching procedure}

111

112 The pseudo-total element concentrations were characterized by aqua regia digestion according to 113 standard ISO 11466 [16] and analyzed with the ICP-OES technique. The 4-step sequential leaching

114 procedure used in this study is presented in Table 2. This procedure is based on the Community Bureau

115 of Reference (BCR) procedure [17]. Stages 2 to 4 follow the BCR procedure, but the first stage

116 involves extraction with deionized water acidified to $\mathrm{pH} 4$ with $\mathrm{HNO}_{3}$ [18]. The purpose of the first

117 stage is to simulate the effect of acidic rainwater - present day rain - on the solubility of the metals. 
118 This 4-step sequential leaching procedure has been used successfully with samples including bottom 119 ash and FA [18-21].

120 The sample mortars were first crushed and sieved to particle sizes smaller than $0.5 \mathrm{~mm}$. The

121 eluates from each step were separated from the residue by centrifuging for $20 \min (\mathrm{RCF}=3000)$ and 122 analyzed using the ICP-OES technique. Duplicate samples from each batch were analyzed, and the 123 averages were calculated. The moisture contents of the FA and the FA granules were measured 124 according to standard SFS-EN 12880 [22] by drying the samples in a hot air oven for $24 \mathrm{~h}$ at $105 \pm 2$ $125{ }^{\circ} \mathrm{C}$. The dried samples were placed in cooling desiccators and weighed. However, the samples were not 126 dried prior the sequential leaching procedure, since heat can affect the leaching of elements [23]. 127 Instead, the moisture contents were taken into account as the leaching results were calculated. The 128 moisture mass fractions of the samples were low: $0.42 \%$ for FA; $1.62 \%$ for FAGR1; and $1.55 \%$ for 129 FAGR2. 
142 Table 2. 4-step sequential leaching procedure $[17,18]$.

\begin{tabular}{|c|c|c|c|}
\hline Step & Fraction & Extractant & Experimental conditions \\
\hline F1 & Water-soluble & $40 \mathrm{~cm}^{3} \mathrm{H}_{2} \mathrm{O}$ at $\mathrm{pH} 4\left(\right.$ with $\mathrm{HNO}_{3}$ ) & $16 \mathrm{~h}$ at $22 \pm 5^{\circ} \mathrm{C}$, constant shaking \\
\hline $\mathrm{F} 2$ & $\begin{array}{l}\text { Exchangeable and } \\
\text { acid soluble }\end{array}$ & $40 \mathrm{~cm}^{3} \mathrm{HOAc} 0.11 \mathrm{~mol} \cdot \mathrm{L}^{-1}$ & $16 \mathrm{~h}$ at $22 \pm 5^{\circ} \mathrm{C}$, constant shaking \\
\hline F3 & Reducible & $\begin{array}{l}40 \mathrm{~cm}^{3} \mathrm{NH}_{2} \mathrm{OH} \cdot \mathrm{HCl} 0.5 \mathrm{~mol} \cdot \mathrm{L}^{-1} \\
\text { at } \mathrm{pH} 1.5\left(\text { with } \mathrm{HNO}_{3}\right)\end{array}$ & $16 \mathrm{~h}$ at $22 \pm 5^{\circ} \mathrm{C}$, constant shaking \\
\hline \multirow[t]{3}{*}{$\mathrm{F} 4$} & Oxidizable & $10 \mathrm{~cm}^{3} \mathrm{H}_{2} \mathrm{O}_{2} 300 \mathrm{~g} \cdot \mathrm{L}^{-1}$ & $\begin{array}{l}1 \mathrm{~h} \text { at } 22 \pm 5^{\circ} \mathrm{C} \text {, occasional manual } \\
\text { shaking, then } 1 \mathrm{~h} 85 \pm 2{ }^{\circ} \mathrm{C} \text {. Reduce } \\
\text { the volume to less than } 3 \mathrm{~cm}^{3}\end{array}$ \\
\hline & & $10 \mathrm{~cm}^{3} \mathrm{H}_{2} \mathrm{O}_{2} 300 \mathrm{~g} \cdot \mathrm{L}^{-1}$ & $1 \mathrm{~h}$ at $85 \pm 2^{\circ} \mathrm{C}$ \\
\hline & & $\begin{array}{l}50 \mathrm{~cm}^{3} \mathrm{NH}_{4} \mathrm{OAc} 1 \mathrm{~mol} \cdot \mathrm{L}^{-1} \text { at } \\
\text { pH } 2\left(\text { with } \mathrm{HNO}_{3}\right)\end{array}$ & $16 \mathrm{~h}$ at $22 \pm 5^{\circ} \mathrm{C}$ \\
\hline
\end{tabular}

144 The fractions of the 4-step sequential leaching are the water-soluble fraction; exchangeable and acid-

145 soluble fraction; reducible fraction; and oxidizable fraction [15]. In theory, the first fraction should

146 contain water-soluble ions. This fraction is the most mobile, and it contains potentially the most readily

147 available metal and metalloid species. The second fraction should contain metals bonded

148 electrostatically, metals bonded with weak covalent bonds, or metals bonded to carbonates. The third

149 fraction should contain metals bonded to Mn and Fe oxides, and the fourth fraction metals bonded to

150 organic matter or to different sulfides and oxides. However, it should be noted that sequential leaching

151 was originally designed for fractionating of sediments. Therefore, the bonding of different metals

152 originating from matrixes that differ notably from sediments, such as FA, cannot be deduced precisely

153 from the sequential leaching results. For example, FA is quite basic, and the acetic acid used in the

154 second step of sequential leaching is not strong enough to acidify the sample matrix. Thus, even if the

155 FA matrix contained some carbonates, they would not dissolve. Furthermore, the reagents used in the 
156 sequential leaching are not completely target specific. However, even when the bonding of metals

157 cannot be deduced from sequential leaching data, it still gives a good estimate of the solubility of

158 metals in real environmental conditions. In the present study, the first two fractions (F1 and F2) are

159 referred to as easily bioavailable fractions. The total bioavailability refers to the sum of the fractions

160 (F1-F4) $[15,17,24]$. Recovery \% of a particular element E was calculated with equation 1:

161

162 Recovery $\%=\left(x(\mathrm{E})_{\mathrm{FAGRi}} / x(\mathrm{E})_{\mathrm{FA}}\right) \cdot 100$

163 where $x=$ content in $\mathrm{mg} \cdot \mathrm{kg}^{-1}$.

164

165

\section{Results and discussion}

166

$167 \quad 3.1$ Contents and leaching of nutrients

168

169 The pseudo-total contents of nutrients $\mathrm{Ca}, \mathrm{K}, \mathrm{Mg}, \mathrm{P}$, and $\mathrm{S}$ are presented in Table 3. FA and the 170 granules FAGR1 and FAGR2 contained plenty of Ca and a lesser degree of the other nutrients.

171 Granulation had a clear effect on the recoveries of $\mathrm{Ca}(81.5 \%), \mathrm{Mg}(77.4 \%)$, and S (65.8 \%) from

172 FAGR1. However, the recoveries of the main nutrients $\mathrm{K}$ and $\mathrm{P}$ were the same before and after

173 granulation. The addition of ammonium sulfate to FAGR2 increased the recoveries of Ca (104.9\%),

$174 \mathrm{Mg}(102.6 \%)$ and S (104.4\%) back to the same levels as those in FA. The Ca content and the K+ P

175 content exceeded the minimum requirements of Finnish Fertilizer Product Decree 24/2011 [10] for

176 forest fertilizers.

177

178

179 
180 Table 3. Pseudo-total contents of nutrients $\mathrm{Ca}, \mathrm{K}, \mathrm{Mg}, \mathrm{P}$, and $\mathrm{S}$ and the limit values of Finnish

181 Fertilizer Product Decree 24/2011 [10].

\begin{tabular}{llllll}
\hline & $\mathrm{Ca}\left(\mathrm{g} \cdot \mathrm{kg}^{-1}\right)$ & $\mathrm{K}\left(\mathrm{g} \cdot \mathrm{kg}^{-1}\right)$ & $\mathrm{P}\left(\mathrm{g} \cdot \mathrm{kg}^{-1}\right)$ & $\mathrm{Mg}\left(\mathrm{g} \cdot \mathrm{kg}^{-1}\right)$ & $\mathrm{S}\left(\mathrm{g} \cdot \mathrm{kg}^{-1}\right)$ \\
\hline FA & 103 & 7.95 & 9.92 & 19.0 & 12.0 \\
FAGR1 & 83.9 & 8.05 & 9.97 & 14.7 & 7.89 \\
Recovery $\%^{1}$ & 81.5 & 101.3 & 100.5 & 77.4 & 65.8 \\
FAGR2 & 108 & 7.98 & 9.90 & 19.5 & 19.0 \\
Recovery $\%^{1}$ & 104.9 & 100.4 & 99.8 & 102.6 & $104.4^{2}$ \\
\hdashline Limit value & $\geq 60$ & $\mathrm{~K}+\mathrm{P} \geq 20$ & & & \\
\hline
\end{tabular}

${ }^{1}$ Recovery $\%=\left(x(\mathrm{E})_{\mathrm{FAGRi}} / x(\mathrm{E})_{\mathrm{FA}}\right) \cdot 100$, where $x(\mathrm{E})=$ content of a particular element $\mathrm{E}$ in $\mathrm{mg} \cdot \mathrm{kg}^{-1}$.

${ }^{2}$ Actual recovery based on original $\mathrm{S}\left(12.0 \mathrm{~g} \cdot \mathrm{kg}^{-1}\right)$ and added $\mathrm{S}\left(6.2 \mathrm{~g} \cdot \mathrm{kg}^{-1}\right)$ contents.

182

183 The total bioavailability $\left(\sum \mathrm{F}_{\mathrm{i}}\right)$ and the amounts of easily bioavailable $(\mathrm{F} 1+\mathrm{F} 2)$ nutrients $\mathrm{Ca}, \mathrm{K}, \mathrm{Mg}, \mathrm{P}$,

184 and $\mathrm{S}$ are presented in Table 4. The results show that granulation had a significant effect on the

185 recoveries of the easily bioavailable $\mathrm{Ca}(67.9 \%), \mathrm{K}(47.5 \%), \mathrm{Mg}(46.7 \%), \mathrm{P}(34.1 \%)$, and S (59.0 \%)

186 from FAGR1 (Table 4). In practice, this means that the quick-acting fertilizer effect of granulated ash

187 FAGR1 is smaller than that of the FA. In addition, the total bioavailability recoveries of Ca (74.1\%), K

188 (83.6\%), $\mathrm{Mg}(54.3 \%)$, and S (59.9\%) decreased after granulation. However, the total bioavailability

189 recovery of $\mathrm{P}(130.6 \%)$ from FAGR1 increased after granulation

190 The addition of ammonium sulfate increased the recoveries of easily bioavailable $\mathrm{Ca}(99.2 \%), \mathrm{K}(96.2$

$191 \%), \mathrm{Mg}(104.0 \%)$ and $\mathrm{S}(100.6 \%)$ from FAGR2 back to the same levels as those in FA. The same was

192 observed for the total bioavailability recoveries of these elements (Ca 100.9 \%; K 97.1 \%; Mg 103.4\%;

193 and S $102.9 \%)$. The recovery of easily bioavailable P (5.6\%) from FAGR2 decreased by $95 \%$

194 compared to that in the case of FA. This decrease in easily bioavailable P could be a desirable property

195 for a granule, especially in the case of an agricultural fertilizer. This is because easily bioavailable $\mathrm{P}$

196 can leach from fields into surface waters causing eutrophication (leading to algal blooms) in nearby 
197 rivers and lakes. The ammonium sulfate addition to FAGR2 did not have an impact on the recovery of

$198 \mathrm{P}(136.3 \%)$ compared to FAGR1.

199 Based on the sequential leaching results, $\mathrm{Ca}, \mathrm{K}, \mathrm{Mg}$, and $\mathrm{S}$ are not only physically encapsulated

200 to the granulated FA but they are instead chemically bonded to the matrix. This behavior was expected

201 especially for Ca and S, since they are the key elements in the self-hardening of ash. Self-hardening

202 begins as calcium oxide $(\mathrm{CaO})$ reacts with water instantly to form calcium hydroxide $\left(\mathrm{Ca}(\mathrm{OH})_{2}\right)$ in an

203 exothermic reaction [25]:

204

205

$$
\mathrm{CaO}+\mathrm{H}_{2} \mathrm{O}->\mathrm{Ca}(\mathrm{OH})_{2}
$$

206

207

$\mathrm{Ca}(\mathrm{OH})_{2}$ gradually reacts with $\mathrm{CO}_{2}$ to form calcium carbonate $\left(\mathrm{CaCO}_{3}\right)[25]$ :

208

209

$$
\mathrm{Ca}(\mathrm{OH})_{2}+\mathrm{CO}_{2}(\mathrm{~g})->\mathrm{CaCO}_{3}+\mathrm{H}_{2} \mathrm{O}
$$

210

211 Carbonation reaction (2) is considered to be the main strength-providing reaction in the self-hardening of ash. $\mathrm{Ca}$ also forms other strength-providing products, such as ettringite $\left(\mathrm{Ca}_{6} \mathrm{Al}_{2}\left(\mathrm{SO}_{4}\right)_{3}(\mathrm{OH})_{12} \cdot 26 \mathrm{H}_{2} \mathrm{O}\right)$ or gypsum $\left(\mathrm{CaSO}_{4} \cdot 2 \mathrm{H}_{2} \mathrm{O}\right)$ if $\mathrm{Al}$ and/or $\mathrm{S}$ are available [26]:

214

215

216

$$
\mathrm{Ca}_{3} \mathrm{Al}_{2} \mathrm{O}_{6}+3 \mathrm{CaSO}_{4} \cdot 2 \mathrm{H}_{2} \mathrm{O}+26 \mathrm{H}_{2} \mathrm{O}->\mathrm{Ca}_{6} \mathrm{Al}_{2}\left(\mathrm{SO}_{4}\right)_{3}(\mathrm{OH})_{12} \cdot 26 \mathrm{H}_{2} \mathrm{O}
$$

217

218 Another earth-alkali metal, $\mathrm{Mg}$, reacts similarly to $\mathrm{Ca}$ during self-hardening, which explains the 219 reduced solubility of $\mathrm{Mg}$. Ettringite is only stable at high $\mathrm{pH}$ values [27], and all other self-hardening 
220 products dissolve during sequential leaching procedure. It is therefore surprising that the total

221 bioavailabilities as well as the pseudo-total recoveries of $\mathrm{Ca}, \mathrm{Mg}$, and $\mathrm{S}$ decreased owing to

222 granulation. This means that these elements also form other, more stable, phases during self-hardening.

223 In fact, Ohenoja et al. [28] studied the self-hardening of peat and wood FA from fluidized bed

224 combustion and discovered that the amount of reactive $\mathrm{SiO}_{2}$ had a clear correlation with the

225 compressive strength of self-hardened FA. It is therefore most likely that these types of FA also form

226 some stable silicate compounds, which would explain the reduced solubility to aqua regia.

227 A very strong odor of ammonia was observed during FAGR2 granulation as ammonium sulfate

228 solution was added to the mixture. It was later discovered that during granulation of FA, the

229 ammonium sulfate $\left(\left(\mathrm{NH}_{4}\right)_{2} \mathrm{SO}_{4}\right)$ reacts with $\mathrm{Ca}(\mathrm{OH})_{2}$ as follows [29]:

230

231

$$
\left(\mathrm{NH}_{4}\right)_{2} \mathrm{SO}_{4}+\mathrm{Ca}(\mathrm{OH})_{2}->\mathrm{CaSO}_{4}+\mathrm{NH}_{3}(\mathrm{~g})+\mathrm{H}_{2} \mathrm{O}
$$

232

233 Calcium sulfate $\left(\mathrm{CaSO}_{4}\right)$ and ammonia $\left(\mathrm{NH}_{3}\right)$ gas are formed in the reaction. In practice, ammonium

234 cannot be added to ash granules this way owing to the reaction with hydroxides and there could even be

235 potential health risks due to the release of ammonia gas. The increase in the pseudo-total content of Ca

236 was higher than the expected increase due to ammonium sulfate addition. It is therefore likely that

237 ammonium sulfate addition hinders some Ca reactions, which causes the increase in the solubility of

238 Ca.

239

240

241

242 
243 Table 4. Amounts of easily bioavailable fractions and total bioavailability of nutrients $\mathrm{Ca}, \mathrm{K}, \mathrm{Mg}, \mathrm{P}$, 244 and $\mathrm{S}$.

\begin{tabular}{|c|c|c|c|c|c|}
\hline & $\mathrm{Ca}\left(\mathrm{g} \cdot \mathrm{kg}^{-1}\right)$ & $\mathrm{K}\left(\mathrm{g} \cdot \mathrm{kg}^{-1}\right)$ & $\mathrm{Mg}\left(\mathrm{g} \cdot \mathrm{kg}^{-1}\right)$ & $\mathrm{P}\left(\mathrm{g} \cdot \mathrm{kg}^{-1}\right)$ & $\mathrm{S}\left(\mathrm{g} \cdot \mathrm{kg}^{-1}\right)$ \\
\hline FA & & & & & \\
\hline $\begin{array}{l}\text { Easily bioavailable } \\
\qquad(\mathrm{F} 1+\mathrm{F} 2)\end{array}$ & 53.0 & 1.83 & 5.76 & 0.323 & 11.0 \\
\hline $\begin{array}{l}\text { Total bioavailability } \\
(\mathrm{F} 1+\mathrm{F} 2+\mathrm{F} 3+\mathrm{F} 4)\end{array}$ & 81.6 & 3.73 & 7.26 & 4.02 & 11.5 \\
\hline FAGR1 & & & & & \\
\hline $\begin{array}{l}\text { Easily bioavailable } \\
\qquad(\mathrm{F} 1+\mathrm{F} 2)\end{array}$ & 36.0 & 0.87 & 2.69 & 0.110 & 6.49 \\
\hline Recovery $\%^{I}$ & 67.9 & 47.5 & 46.7 & 34.1 & 59.0 \\
\hline $\begin{array}{l}\text { Total bioavailability } \\
(\mathrm{F} 1+\mathrm{F} 2+\mathrm{F} 3+\mathrm{F} 4)\end{array}$ & 60.5 & 3.12 & 3.94 & 5.24 & 6.89 \\
\hline $\begin{array}{c}\text { Recovery } \%^{l} \\
\text { FAGR2 }\end{array}$ & 74.1 & 83.6 & 54.3 & 130.3 & 59.9 \\
\hline $\begin{array}{l}\text { Easily bioavailable } \\
\qquad(\mathrm{F} 1+\mathrm{F} 2)\end{array}$ & 52.6 & 1.76 & 5.99 & 0.018 & 17.3 \\
\hline Recovery $\%^{l}$ & 99.2 & 96.2 & 104.0 & 5.6 & 100.6 \\
\hline $\begin{array}{l}\text { Total bioavailability } \\
(\mathrm{F} 1+\mathrm{F} 2+\mathrm{F} 3+\mathrm{F} 4)\end{array}$ & 82.3 & 3.62 & 7.51 & 5.48 & 17.7 \\
\hline Recovery $\%^{1}$ & 100.9 & 97.1 & 103.4 & 136.3 & $102.9^{2}$ \\
\hline
\end{tabular}

${ }^{1}$ Recovery $\%=\left(x(\mathrm{E})_{\mathrm{FAGR}} / x(\mathrm{E})_{\mathrm{FA}}\right) \cdot 100$, where $x(\mathrm{E})=$ content of a particular element $\mathrm{E}$ in $\mathrm{mg} \cdot \mathrm{kg}^{-1}$.

${ }^{2}$ Actual recovery based on original $\mathrm{S}\left(12.0 \mathrm{~g} \cdot \mathrm{kg}^{-1}\right)$ and added $\mathrm{S}\left(6.2 \mathrm{~g} \cdot \mathrm{kg}^{-1}\right)$ contents.

$246 \quad 3.2$ Contents and leaching of harmful elements

247

248 The pseudo-total contents of the harmful metals $\mathrm{As}, \mathrm{Cd}, \mathrm{Cr}, \mathrm{Cu}, \mathrm{Ni}, \mathrm{Pb}$ and $\mathrm{Zn}$ are presented in Table

249 5. The pseudo-total contents of all the harmful metals were small and they were clearly below the limit

250 values of Finnish Fertilizer Product Decree 24/2011 [10] for forest fertilizers. The recoveries of As

251 (72.0 \%), $\mathrm{Cd}(73.7 \%)$, and $\mathrm{Cu}(87.4 \%)$ were smaller from the FAGR1 than from FA, but the

252 recoveries of $\mathrm{Cr}(95.7 \%), \mathrm{Ni}(92.2 \%), \mathrm{Pb}(106.5 \%)$, and $\mathrm{Zn}(95.1 \%)$ were roughly the same before 
253 and after granulation. Ammonium sulfate addition increased the recoveries of As (108.0\%), Cd (105.3

$254 \%)$, and $\mathrm{Cu}(102.9 \%)$ from FAGR2 back to the same levels as those in the FA.

255

256 Table 5. Pseudo-total contents of harmful metals $\mathrm{As}, \mathrm{Cd}, \mathrm{Cr}, \mathrm{Cu}, \mathrm{Ni}, \mathrm{Pb}$, and $\mathrm{Zn}$ and the limit values of

257 Finnish Fertilizer Product Decree 24/2011 [10].

\begin{tabular}{llllllll}
\hline & $\begin{array}{l}\mathrm{As} \\
\left(\mathrm{mg} \cdot \mathrm{kg}^{-1}\right)\end{array}$ & $\begin{array}{l}\mathrm{Cd} \\
\left(\mathrm{mg} \cdot \mathrm{kg}^{-1}\right)\end{array}$ & $\begin{array}{l}\mathrm{Cr} \\
\left(\mathrm{mg} \cdot \mathrm{kg}^{-1}\right)\end{array}$ & $\begin{array}{l}\mathrm{Cu} \\
\left(\mathrm{mg} \cdot \mathrm{kg}^{-1}\right)\end{array}$ & $\begin{array}{l}\mathrm{Ni} \\
\left(\mathrm{mg} \cdot \mathrm{kg}^{-1}\right)\end{array}$ & $\begin{array}{l}\mathrm{Pb} \\
\left(\mathrm{mg} \cdot \mathrm{kg}^{-1}\right)\end{array}$ & $\begin{array}{l}\mathrm{Zn} \\
\left(\mathrm{mg} \cdot \mathrm{kg}^{-1}\right)\end{array}$ \\
\hline FA & 25 & 1.9 & 69 & 87 & 51 & 31 & 284 \\
FAGR1 & 18 & 1.4 & 66 & 76 & 47 & 33 & 270 \\
Recovery $\%^{1}$ & 72.0 & 73.7 & 95.7 & 87.4 & 92.2 & 106.5 & 95.1 \\
FAGR2 & 27 & 2.0 & 71 & 91 & 52 & 31 & 300 \\
Recovery $\%^{1}$ & 108.0 & 105.3 & 102.9 & 104.6 & 102.0 & 100.0 & 111.1 \\
\hdashline $\begin{array}{l}\text { Limit value } \\
\text { Field/forest }\end{array}$ & $25 / 40$ & $2.5 / 25$ & $300 / 300$ & $600 / 700$ & $100 / 150$ & $100 / 150$ & $1500 / 4500$ \\
fertilizers & & & & & & & \\
\hline
\end{tabular}

${ }^{1}$ Recovery $\%=\left(x(\mathrm{E})_{\mathrm{FAGRi}} / x(\mathrm{E})_{\mathrm{FA}}\right) \cdot 100$, where $x(\mathrm{E})=$ content of a particular element $\mathrm{E}$ in $\mathrm{mg} \cdot \mathrm{kg}^{-1}$.

259 Sequential leaching results of harmful metals $\mathrm{As}, \mathrm{Cd}, \mathrm{Cr}, \mathrm{Cu}, \mathrm{Ni}, \mathrm{Pb}$, and $\mathrm{Zn}$ are presented in Table 6.

260 The amounts of water-soluble fraction F1 were mostly below the determination limits, and the total

261 bioavailabilities were small. Therefore, a comparison between FA and granules FAGR1 and FAGR2 is

262 not meaningful. However, the total bioavailability recoveries of $\mathrm{Zn}(58.2 \%)$ and $\mathrm{Cr}(82.9 \%)$ from the

263 FAGR1 decreased owing to granulation. The recoveries of both $\mathrm{Zn}(115 \%)$ and $\mathrm{Cr}(102 \%)$ increased

264 after ammonium sulfate addition to FAGR2. When the pseudo-total contents (Table 5) and sequential

265 leaching data (Table 6) are compared, it is found that most of the harmful metals dissolve only with

266 aqua regia digestion, and therefore, the aqua regia digestion is a poor estimate of the bioavailability of 
267 these metals. In practice, the total bioavailability of these metals is very low, and this does not limit the

268 usability of FA as a fertilizer in agriculture or forestry.

269

270 Table 6. Sequential leaching results of harmful metals $\mathrm{As}, \mathrm{Cd}, \mathrm{Cr}, \mathrm{Cu}, \mathrm{Ni}, \mathrm{Pb}$, and $\mathrm{Zn}$.

\begin{tabular}{llllllll}
\hline & $\begin{array}{l}\mathrm{As} \\
\left(\mathrm{mg} \cdot \mathrm{kg}^{-1}\right)\end{array}$ & $\begin{array}{l}\mathrm{Cd} \\
\left(\mathrm{mg} \cdot \mathrm{kg}^{-1}\right)\end{array}$ & $\begin{array}{l}\mathrm{Cr} \\
\left(\mathrm{mg} \cdot \mathrm{kg}^{-1}\right)\end{array}$ & $\begin{array}{l}\mathrm{Cu} \\
\left(\mathrm{mg} \cdot \mathrm{kg}^{-1}\right)\end{array}$ & $\begin{array}{l}\mathrm{Ni} \\
\left(\mathrm{mg} \cdot \mathrm{kg}^{-1}\right)\end{array}$ & $\begin{array}{l}\mathrm{Pb} \\
\left(\mathrm{mg} \cdot \mathrm{kg}^{-1}\right)\end{array}$ & $\begin{array}{l}\mathrm{Zn} \\
\left(\mathrm{mg} \cdot \mathrm{kg}^{-1}\right)\end{array}$ \\
\hline FA & & & & & & & \\
F1 & $<1.2$ & $<0.04$ & 0.8 & $<0.1$ & $<0.1$ & $<0.4$ & 0.1 \\
F2 & $<1.2$ & 0.50 & 1.1 & 2.3 & 2.7 & 0.6 & 33 \\
F3 & 3.7 & 0.38 & 1.7 & 7.2 & 0.8 & 4.4 & 31 \\
F4 & $<1.5$ & 0.06 & 1.4 & 2.5 & 0.5 & 2.4 & 5 \\
FAGR1 & & & & & & & \\
F1 & $<1.2$ & $<0.04$ & 0.4 & $<0.1$ & $<0.1$ & $<0.4$ & 0.1 \\
F2 & $<1.2$ & 0.41 & 0.9 & 2.9 & 2.7 & 0.9 & 19 \\
F3 & 5.2 & 0.33 & 1.8 & 7.3 & 0.9 & 9 & 18 \\
F4 & $<1.5$ & $<0.05$ & 1 & 2.5 & 0.3 & 3.5 & 3.1 \\
FAGR2 & & & & & & & \\
F1 & $<1.2$ & $<0.04$ & 0.6 & $<0.1$ & $<0.1$ & $<0.4$ & 0.04 \\
F2 & $<1.2$ & 0.54 & 0.6 & 2 & 2.5 & 0.7 & 44 \\
F3 & 6.8 & 0.41 & 1.9 & 8 & 1 & 5.7 & 31 \\
F4 & 1.7 & 0.08 & 2 & 3.4 & 0.7 & 3.7 & 4.4 \\
\hline
\end{tabular}

271

272 4. Conclusions

273

274 A sequential leaching procedure and pseudo-total acid digestion were used to investigate the effect of

275 granulation and ammonium sulfate addition on the solubility and bioavailability of nutrients and

276 harmful elements in peat and wood co-combustion FA. Results indicated that granulation significantly

277 reduced the recoveries of the easily bioavailable nutrients $\mathrm{Ca}, \mathrm{K}, \mathrm{Mg}, \mathrm{P}$, and $\mathrm{S}$. This means that

278 granulation reduces the quick-acting fertilizer effect of FA. Results also indicated that the total

279 bioavailability of $\mathrm{Ca}, \mathrm{K}, \mathrm{Mg}$, and $\mathrm{S}$ reduced after granulation. Therefore, the fertilizing effect of FA 
280 reduces after granulation. Owing to the reduced pseudo-total recovery of $\mathrm{Ca}, \mathrm{Mg}$, and $\mathrm{S}$ after

281 granulation, it is most likely that these types of FA also form some very stable silicate compounds

282 besides the common self-hardening products. Addition of ammonium sulfate increases the recoveries

283 of easily bioavailable nutrients and the total bioavailability recoveries of the $\mathrm{Ca}, \mathrm{K}$, and $\mathrm{Mg}$ back on the

284 same levels as those in FA, and the recoveries of S are increased owing to the increased sulfate content.

285 The sequential leaching results indicate that the total bioavailability of the harmful elements As, $\mathrm{Cd}$,

$286 \mathrm{Cr}, \mathrm{Cu}, \mathrm{Ni}, \mathrm{Pb}$, and $\mathrm{Zn}$ is very low, and this does not limit the usability of $\mathrm{FA}$ as a fertilizer in

287 agriculture or forestry.

288

289 Acknowledgements

290

291 This work was done under the auspices of the Biotuhka (Bioash) ERDF Project (project no: A70101,

292 funded by North Ostrobothnia Centre for Economic Development, Transport and the Environment;

293 Napapiirin Vesi ja Energia Ltd.; Napapiirin Residuum Ltd. and Rovaniemen Kehitys Ltd.). PhD Ville

294 Kuokkanen is acknowledged for the granulation experiments. The staff at the Natural Resources

295 Institute Finland laboratory in Rovaniemi and in Vantaa are acknowledged for the laboratory analyses.

296

297 References

298

299 [1] European Commission, Europe 2020, 2017. http://ec.europa.eu/europe2020/index_en.htm

$300 \quad$ (Accessed on March 1, 2017).

301 [2] European Commission, Circular Economy Strategy, 2017.

302 http://ec.europa.eu/environment/circular-economy/index_en.htm (Accessed on March 1, 2017). 
303 [3] Directive 2008/98/EC of the European Parliament and of the Council of 19 November 2008 on 304 waste and repealing certain Directives. 2008.11.19, Off. J. EU L 312 (2008) 3-30.

305 [4] E. Karltun, A. Saarsalmi, M. Ingerslev, M. Mandre, S. Andersson, T. Gaitnieks, R. Ozolinčius, I. 306 Varnagiryte-Kabasinskiene, Wood Ash Recycling - Possibilities And Risks, in: D. Röser, A.

307 Asikainen, K. Raulund-Rasmussen, I. Stupak (Eds.), Sustainable Use of Forest Biomass for 308 Energy: A Synthesis with Focus on the Baltic and Nordic Region, Springer Netherlands, $309 \quad$ Dordrecht, 2008, pp. 79-108.

310 [5] M. Moilanen, K. Silfverberg, H. Hökkä, J. Issakainen, Comparing Effects of Wood Ash and 311 Commercial PK Fertiliser on the Nutrient Status and Stand Growth of Scots Pine on Drained 312 Mires, Balt. For. 10 (2004) 1-10.

313 [6] M. Moilanen, J. Hytönen, H. Hökkä, A. Ahtikoski, Fertilization increased growth of scots pine 314 and financial performance of forest management in a drained peatland in Finland, Silva Fenn. 49 315 (2015). https://doi.org/10.14214/sf.1301.

316 [7] H. Rasmusson, S. Sarenbo, T. Claesson, Ash Products and Their Economic Profitability, Open 317 Waste Manag. J. 6 (2013) 1-5.

318 [8] J. Pesonen, V. Kuokkanen, T. Kuokkanen, M. Illikainen, Co-granulation of bio-ash with sewage 319 sludge and lime for fertilizer use, J. Environ. Chem. Eng. 4 (2016) 4817-4821.

320 [9] Government Decree 591/2006 concerning the recovery of certain wastes in earth construction, 3212006.

322 [10] The Decree of the Ministry of Agriculture and Forestry on Fertiliser Products 24/11, 2011.

323 [11] Council Directive 1999/31/EC of 26 April 1999 on the landfill of waste. 1999.04.26, Off. J. EC L 324 182 (1999) 1-19. 
[12] Council Directive 86/278/EEC of 12 June 1986 on the protection of the environment, and in particular of the soil, when sewage sludge is used in agriculture. 1986.06.12, Off. J. EC L 181 (1986) 6-12.

[13] J. Kaakinen, T. Kuokkanen, K. Kujala, I. Välimäki, H. Jokinen, The Use of a Five-stage Sequential Leaching Procedure for Risk Assessment of Heavy Metals in Waste Rock Utilized in Railway Ballast, Soil Sediment Contam. Int. J. 21 (2012) 322-334.

[14] Bioavailability of Contaminants in Soils and Sediments: Processes, Tools, and Applications, National Academies Press, Washington, D.C., 2003.

[15] A.V. Filgueiras, I. Lavilla, C. Bendicho, Chemical sequential extraction for metal partitioning in environmental solid samples, J. Environ. Monit. 4 (2002) 823-857.

[16] ISO 11466:1995 - Soil quality -- Extraction of trace elements soluble in aqua regia, International Organization of Standardization, Geneva, Switzerland, 1995.

[17] G. Rauret, J.F. López-Sánchez, A. Sahuquillo, R. Rubio, C. Davidson, A. Ure, P. Quevauviller, Improvement of the BCR three step sequential extraction procedure prior to the certification of new sediment and soil reference materials, J. Environ. Monit. 1 (1999) 57-61.

[18] H. Nurmesniemi, R. Pöykiö, T. Kuokkanen, P. Perämäki, I. Välimäki, Sequential leaching of trace elements in bottom ash from a fluidized bed co-combustion boiler at a pulp and paper mill complex, J. Solid Waste Technol. Manag. 31 (2005) 115-121.

[19] T. Kuokkanen, R. Pöykiö, H. Nurmesniemi, J. Rämö, Sequential leaching of heavy metals and sulfur in bottom ash and fly ash from the co-combustion of wood and peat at a municipal district heating plant, Chem. Speciat. Bioavailab. 18 (2006) 131-142.

[20] H. Nurmesniemi, R. Pöykiö, T. Kuokkanen, J. Rämö, Chemical sequential extraction of heavy metals and sulphur in bottom ash and in fly ash from a pulp and paper mill complex, Waste Manag. Res. 26 (2008) 389-399. 
349 [21] R. Pöykiö, H. Nurmesniemi, P. Perämäki, T. Kuokkanen, I. Välimäki, Leachability of metals in

350 fly ash from a pulp and paper mill complex and environmental risk characterisation for eco-

351 efficient utilization of the fly ash as a fertilizer, Chem. Speciat. Bioavailab. 17 (2005) 1-10.

352 [22] SFS-EN 12880 Characterization of sludges. Determination of dry residue and water content,

$353 \quad$ Finnish Standards Association, Helsinki, Finland, 2001.

354 [23] D.S. Kosson, D.S. Van, F. Sanchez, A.C. Garrabrants, An Integrated Framework for Evaluating

355

356

357

358

359

360

361

362

363

364

365

366

367

368

369

370
Leaching in Waste Management and Utilization of Secondary Materials, Environ. Eng. Sci. 19 (2002) 159-204.

[24] A. Tessier, P.G.C. Campbell, M. Bisson, Sequential extraction procedure for the speciation of particulate trace metals, Anal. Chem. 51 (1979) 844-851.

[25] S. Isännäinen, S. Huotari, H. Mursunen, Lentotuhkan itsekovetus, Metsäteho, Helsinki, 1997.

[26] M. Illikainen, P. Tanskanen, P. Kinnunen, M. Körkkö, O. Peltosaari, V. Wigren, J. Österbacka, B. Talling, J. Niinimäki, Reactivity and self-hardening of fly ash from the fluidized bed combustion of wood and peat, Fuel. 135 (2014) 69-75.

[27] S.C.B. Myneni, S.J. Traina, T.J. Logan, Ettringite solubility and geochemistry of the $\mathrm{Ca}(\mathrm{OH}) 2-$ A12(SO4)3-H2O system at 1 atm pressure and 298 K, Chem. Geol. 148 (1998) 1-19.

[28] K. Ohenoja, P. Tanskanen, V. Wigren, P. Kinnunen, M. Körkkö, O. Peltosaari, J. Österbacka, M. Illikainen, Self-hardening of fly ashes from a bubbling fluidized bed combustion of peat, forest industry residuals, and wastes, Fuel. 165 (2016) 440-446.

[29] R. Petrucci, G. Herring, J. Madura, C. Bissonnette, Acids and Bases, in: General Chemistry Principles and Modern Applications, 10th ed., Pearson Canada, Toronto, 2011, pp. 697-744. 